\title{
Calcium Dependence of Large Dense-Cored Vesicle Exocytosis Evoked by Calcium Influx in Bovine Adrenal Chromaffin Cells
}

\author{
Kathrin L. Engisch and Martha C. Nowycky \\ Department of Neurobiology and Anatomy, Medical College of Pennsylvania and Hahnemann University, \\ Philadelphia, Pennsylvania 19129
}

\begin{abstract}
We used the perforated-patch technique to examine the relationship between $\mathrm{Ca}^{2+}$ entry and exocytosis of large dense-cored vesicles in bovine adrenal chromaffin cells. Exocytosis evoked by single-step depolarizations was monitored by capacitance detection. $\mathrm{Ca}^{2+}$ entry was varied by changing external calcium concentration, stepping to different test potentials, depolarizing for different durations, or applying blockers of specific calcium channel subtypes. Regardless of protocol, the amount of exocytosis was strictly related to the integral of the voltage-clamped calcium cur-
\end{abstract}

rent, raised to a power of $\sim 1.5$. Thus, despite the complexities of transient and nonuniform changes in submembrane calcium concentration produced by voltage-gated calcium entry, the calcium dependence of large dense-cored vesicle fusion under conditions of minimal stimulation is well approximated by a simple transfer function of summed calcium entry.

Key words: exocytosis; calcium-sccretion coupling; chromaffin cell; perforated patch; capacitance measurement; calcium channel subtype
It is known that calcium entry is required for the release of hormones, peptides, and catecholamines, which are packaged in large dense-cored vesicles (Douglas, 1968; for review, see Thomas-Reetz and De Camilli, 1994), but a simple quantitative relationship between calcium and large dense-cored vesicle exocytosis has proven elusive. The paucity of quantitative information has been attributed primarily to an absence of sensitive, rapid detectors of neuroendocrine release. Moreover, the exact concentration of calcium at intracellular sites of release cannot yet be determined accurately.

Recently, a method of measuring vesicle fusion by detecting capacitance changes in whole-cell voltage clamp (Neher and Marty, 1982; Joshi and Fernandez, 1988; Fidler and Fernandez, 1989) has enabled neuroendocrine release to be assayed with time resolution on the order of milliseconds. Furthermore, the difficulty in quantifying localized changes in $\left[\mathrm{Ca}^{2+}\right]_{i}$ after the opening of voltage-gated calcium channels has been circumvented by increasing intracellular calcium uniformly, using flash photolysis of DM-Nitrophen (Neher and Zucker, 1993; Thomas et al., 1993a,b; Heinemann et al., 1994).

Despite these technical advances, a consistent "input-output" relationship for $\left[\mathrm{Ca}^{2+}\right]_{\mathrm{i}}$ and large dense-cored vesicle exocytosis still has not been obtained. The rapid and uniform increase in intracellular $\left[\mathrm{Ca}^{2+}\right]_{i}$ induced by flash photolysis of DM-Nitrophen reveals an unexpected level of complexity involved in exocytosis of large dense-cored vesicles in melanotrophs (Thomas et al.,

Received Sept. 5, 1995; revised Nov. 20, 1995; accepted Nov. 29, 1995

This research was supported by grants from the National Institute of Neurological and Communicative Disorders and Stroke (NS22281) and the Muscular Dystrophy Association. We thank Drs. S. Garber, L. Lillien, A. Fomina, and M. Rich for critical reading of this manuscript, Drs. A. Fomina and N. Chernevskaya for many helpful discussions throughout the project, and N. Cook for preparation of adrenal chromaffin cells $\omega$-Agatoxin IVA was a generous gift from Dr. N. Saccomano, Pfizer Pharmaceuticals (Groton, CT).

Correspondence should be addressed to Dr. Kathrin L. Engisch, Department of Neurobiology and Anatomy, Mcdical College of Pennsylvania, 3200 Henry Avenue, Philadelphia, PA 19129.

Copyright (C) 1996 Society for Ncuroscience $0270-6474 / 96 / 161359-11805.00 / 0$ 1993a,b) and bovine adrenal chromaffin cells (Neher and Zucker, 1993; Heinemann et al., 1994). For example, in bovine chromaffin cells, the exocytotic response evoked by flash photolysis of DM Nitrophen consists of a series of kinetic components that decay with exponential time courses and are termed ultrafast $(200-$ 50,000 vesicles/sec), fast ( 100 vesicles/sec), and slow ( $<20$ vesicles/ sec) (Neher and Zucker, 1993).

Multiple kinetic components are also seen in response to calcium influx. In one secretory mode, large dense-cored vesicles can be released by single action potentials (Zhou and Misler, 1995) or brief pulses (Ammala et al., 1993; Horrigan and Bookman, 1994; Seward and Nowycky, 1996), but this response is rapidly lost during whole-cell dialysis of bovine adrenal chromaffin cells (Seward and Nowycky, 1996). In a second secretory mode, trains of stimuli are required to evoke release of large dense-cored vesicles (Augustine and Neher, 1992; Ammala et al., 1993; Peng and Zucker, 1993; Artalejo et al., 1994; Seward et al., 1995; Zhou and Misler, 1995; Seward and Nowycky, 1996). Further complexity is introduced by calcium channel subtypes, which may be differentially coupled to secretion (Artalejo et al., 1994). Finally, during repetitive stimulation of rat adrenal chromaffin cells, the amount of release per action potential increases (Zhou and Misler, 1995), indicating that activity can affect stimulus-secretion coupling of large dense-cored vesicles.

Here we have used phase tracking measurements of capacitance changes to examine the calcium dependence of large densecored vesicle exocytosis in perforated-patch recordings under conditions of minimal stimulation. Because loss of critical cytoplasmic constituents is prevented, the secretory response of bovine chromaffin cells in perforated-patch recordings is stable for 1-2 hr (Gillis et al., 1991), and exocytosis under different experimental conditions can be compared in a single cell. Intracellular calcium concentration was varied by experimentally affecting parameters of the voltage-clamped calcium current. Single step depolarizations were applied to avoid activity-dependent effects on secretory responsiveness. 
We found that when activity-dependent changes in secretory behavior were minimized, a consistent input-output relationship between amount of exocytosis and integrated calcium current was obtained. The calcium dependence of exocytosis was similar for a wide range of different calcium entry dynamics. Our results suggest that exocytosis of large dense-cored vesicles occurs via a probabilistic mechanism that depends on both calcium concentration and the length of time it remains elevated.

\section{MATERIALS AND METHODS}

Chromaffin cell culture. Adult bovine chromaffin cells were prepared by collagenase digestion as described in Vitale et al. (1991). After purification on a Percoll gradient, cells were plated in $10 \%$ fetal calf serum/ DMEM (containing the antibiotics penicillin and streptomycin and the mitotic inhibitors cytosine arabinoside and fluorodeoxyuridine) on collagen-coated glass coverslips at a density of $1.5 \times 10^{5}$ cells $/ 12 \mathrm{~mm}$ coverslip. Recordings were performed between 2 and $7 \mathrm{~d}$ after plating; culture media were partially replaced on day 3 .

Solutions. The standard extracellular solution contained (in $\mathrm{mM}$ ): 130 $\mathrm{NaCl}, 2 \mathrm{KCl}, 10$ glucose, $10 \mathrm{HEPES}, 1 \mathrm{MgCl}_{2}$, and $5 \mathrm{CaCl}_{2}, \mathrm{pH} 7.2$. Changes in ionic composition were always compensated for by osmotic substitution with $\mathrm{N}$-methyl-D-glucamine (for positively charged species, i.e., $\mathrm{Na}^{+}$and $\mathrm{Ca}^{2+}$ ) or aspartic acid (for negatively charged species, i.e., $\mathrm{Cl}^{-}$). Tetrodotoxin was omitted because the toxin slows down $\mathrm{Na}^{+}$ channel gating kinetics by 10-fold, so that gating is detected as an apparent capacitance increase (Horrigan and Bookman, 1993). Capacitance jumps of no more than 2-4 fF were evoked under conditions of $\sim 0$ calcium entry but substantial sodium entry (depolarizations to $-20 \mathrm{mV}$ ), suggesting that $\mathrm{Na}^{+}$channcl gating current is not a major contaminant in our experiments (Horrigan and Bookman, 1994).

Perforated-patch solution contained $135 \mathrm{~mm}$ cesium glutamate, $10 \mathrm{~mm}$ HEPES, $9.5 \mathrm{mM} \mathrm{NaCl}, 0.5 \mathrm{mM}$ bis(2-aminophenoxy)ethane- $N, N, N^{\prime}, N^{\prime}$,tetra-acetic acid and $0.4-0.5 \mathrm{mg} / \mathrm{ml}$ of the pore-forming antibiotic amphotericin B (Rae et al., 1991). All compounds were obtained from Sigma (St. Louis, MO), except for CsOH (ICN, Aurora, OH), SKF-38393 (RBI, Natwick, MA), $\omega$-conotoxin GVIA (Bachem, King of Prussia, PA), $\omega$-agatoxin IVA (generous gift of Dr. N. Saccomano, Pfizer Pharmaceuticals), glutamic acid, BAPTA, and amphotericin B (Calbiochem, La Jolla, CA). Stock solution $(125 \mathrm{mg} / \mathrm{ml})$ of amphotericin B in dimethylsulfoxide was prepared by sonication every $2 \mathrm{hr}$, and $3 \mu \mathrm{l}$ of the stock was added to $700-1000 \mu \mathrm{l}$ of internal solution, followed by $10-30 \mathrm{sec}$ of homogenization with a Pro-250 homogenizer, immediately before filling the patch pipette. Pipettes were predipped in amphotericin B-free solution for $10-20 \mathrm{sec}$ and then backfilled with amphotericin B-containing solution.

Electrophysiological recordings. After seal formation, capacitance measurements were begun when access conductance reached $70 \mathrm{nS}$ (range, 70-140 nS) and were performed with a List EPC7 (List Electronic, Darmstadt, Germany), as described previously (Lim et al., 1990), using a software-based phase-tracking method written in Axobasic. Details are as described in Seward et al. (1995). All experiments were performed at room temperature.

Data analysis. $\Delta \mathrm{Cm}$ and $\Sigma \mathrm{Ca}^{2+}$ entry triggered by single voltage pulses were determined offline using software written in Axobasic. To determine the size of $\mathrm{Cm}$ jumps, $10 \mathrm{Cm}$ points (time resolution, $22 \mathrm{msec} /$ point) immediately before application of the pulse were averaged and subtracted from the first 10 points after the return to capacitance sampling at the end of the depolarization. Capacitance changes were calibrated using a known $100 \mathrm{fF}$ displacement of the capacitance trace (Fidler and Fernandez, 1989). If rapid endocytosis occurred, $2-4$ points were sampled to estimate the peak increase in capacitance. Calcium entry, in number of ions, was calculated by integration of calcium currents (limits for integration were set after $>80 \%$ of the $\mathrm{Na}^{+}$current had decayed $(\sim 2$ msec) and excluded tail currents, which are composed of at least one calcium-activated conductance of unknown origin (see Results, Fig. 1), and division by the elementary charge per ion, in coulombs. All currents were digitally leak-subtracted, using a scaled current response obtained by stepping to $-110 \mathrm{mV}$ for the same duration as the test pulse.

Curve fitting employed a Marquardt-Levenberg, nonlinear leastsquares fitting algorithm (Origin software, Microcal, Northhampton, MA) to fit data by the equation $Y=A \times X^{B}$. In the fitting routine, iterations continued until the $\chi^{2}$ value achieved a minimum and varied $<0.05 \%$ from one iteration to the next. Data were also plotted on logarithmic coordinates, and an "apparent" linear fit of the equation $\log Y=A \times \log X+C$ was obtained.

\section{RESULTS}

\section{Phase tracking in perforated-patch recordings}

Figure 1 illustrates typical capacitance $(C)$ and conductance $(G)$ responses of a single bovine adrenal chromaffin cell, obtained by using the perforated-patch variant of the whole-cell patch-clamp technique. Exocytosis was evoked with single depolarizations to $+20 \mathrm{mV}$ for $5 \mathrm{msec}$ (Fig. 1A), $40 \mathrm{msec}$ (Fig. 1B), $80 \mathrm{msec}$ (Fig. $1 C$ ), and $640 \mathrm{msec}$ (Fig. $1 D$ ). In perforated-patch recordings, a significant increase in capacitance was always accompanied by a similar but opposite change in conductance. The entry of calcium seemed to induce not only exocytosis but also a calciumdependent increase in conductance. The conductance change was not reduced significantly by decreasing external chloride ions ( $\sim 75 \mathrm{~mm}$ in Fig. 1) or external sodium ions (data not shown).

The conductance measurement obtained during phase tracking reflects a combination of membrane conductance and access resistance. Furthermore, in phase tracking, conductance and capacitance measurements are not acquired independently, and if the phase angle is in error, there may be large deviations on the capacitance or conductance trace attributable to changes in the other quantity (Fidler and Fernandez, 1989). Therefore, we made direct measurements of membrane conductance changes induced by calcium entry by giving brief hyperpolarizing and depolarizing voltage pulses $( \pm 20 \mathrm{mV})$ at $1 \mathrm{~Hz}$. The first small test pulse occurred $200 \mathrm{msec}$ after a stimulating pulse that evoked a calcium current. Conductances calculated directly from test pulses $(G=$ $I / V), G_{\mathrm{h}}$ (hyperpolarizing), and $G_{\mathrm{d}}$ (depolarizing) are plotted below the capacitance and conductance traces obtained for the same cell with phase tracking (Fig. 1).

Membrane conductance at rest was $\sim 0.2 \mathrm{nS}$ (corresponding to $R_{\mathrm{m}}=5 \mathrm{G} \Omega$ ), and it increased to at least $0.4 \mathrm{nS}$ after calcium entry. The conductance increase lasts for $\sim 2 \mathrm{sec}$ (confirmed with test pulses given at $2.5 \mathrm{~Hz}$; data not shown). These results indicate that the maintained $G$ trace displacement in response to a $640 \mathrm{msec}$ pulse (Fig. $1 D$ ) is not attributable to a prolonged increase in membrane conductance. In addition, because the decay of the $G$ trace does not mirror that of the $C$ trace, and manual displacement of either capacitance or conductance compensation immediately after stimulus-induced capacitance increases of $>100 \mathrm{fF}$ indicate correct alignment of the phase angle, we conclude that the long-lasting displacement of the $G$ trace is attributable to an increase in access resistance. Such a change would not affect the capacitance measurement, as long as the phase detector was aligned properly (Fidler and Fernandez, 1989).

\section{Avoiding the effects of activity-dependent changes in calcium-secretion coupling}

In preliminary experiments, we found that after significant calcium entry, evoked by single pulses $>80 \mathrm{msec}$, a subsequent response to a standard $40 \mathrm{msec}$ pulse was increased or "facilitated." Even at stimulus intervals of $>3 \mathrm{~min}$, the facilitation did not decay in the absence of stimulation. A second response, however, did not show evidence of facilitation. Therefore, cells were routinely stimulated with a $40 \mathrm{msec}$ pulse after any prolonged calcium entry. Regardless of amplitude, responses immediately after stimulations of pulse duration $>80 \mathrm{msec}$ were not included in the data presented below. 


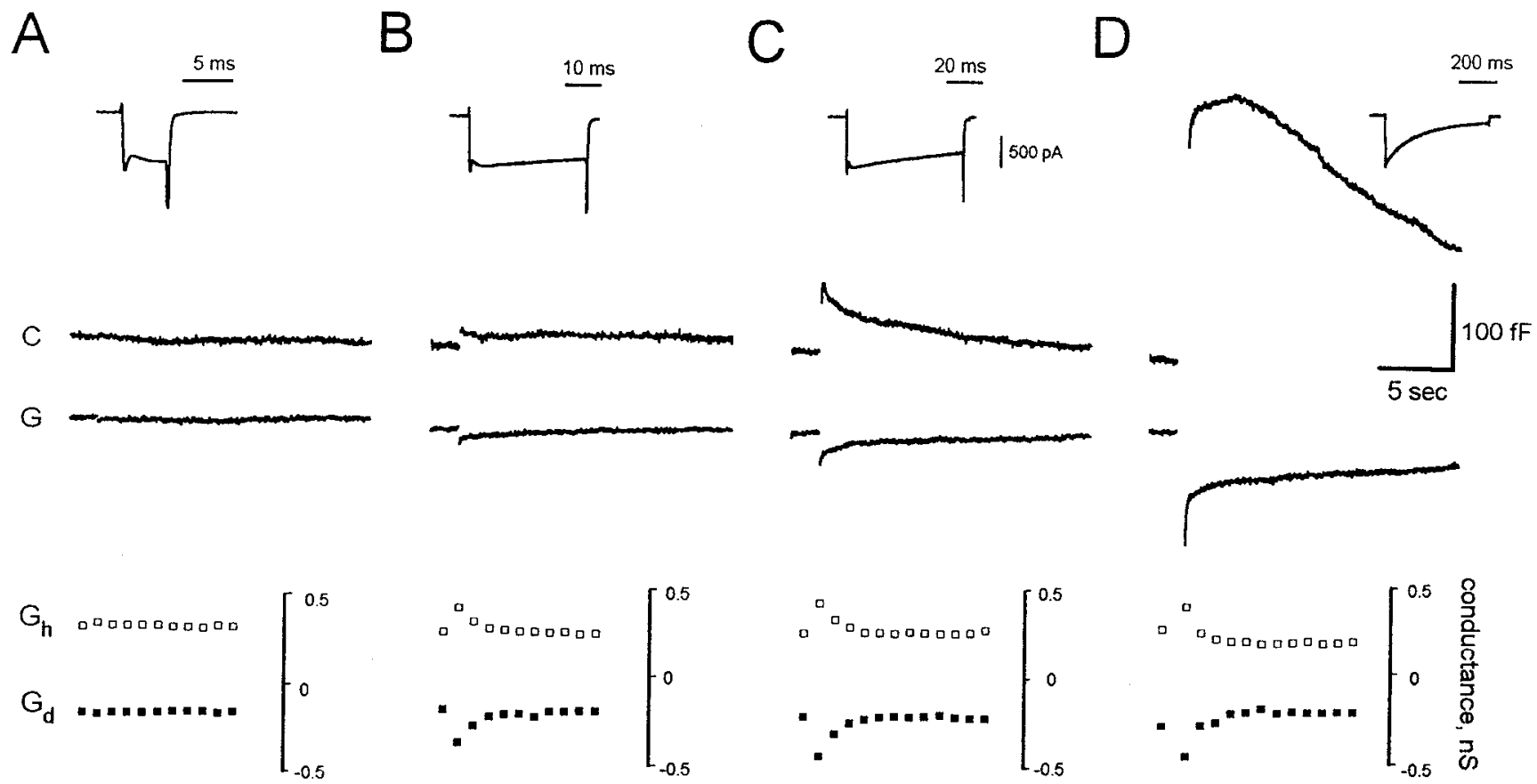

Figure 1. Capacitance and conductance changes in response to single step depolarizations in perforated-patch recordings. From a holding potential of $-90 \mathrm{mV}$, an individual bovine chromaffin cell was stepped to $+20 \mathrm{mV}$ for $5 \mathrm{msec}(A), 40 \mathrm{msec}(B), 80 \mathrm{msec}(C)$, and $640 \mathrm{msec}(D)$. Cm jumps $(\mathrm{small}$ capital $C$ below $A$ ) were larger with increasing pulse length, from $<5 \mathrm{fF}$, for a 5 msec pulse, to $>250 \mathrm{fF}$ after a pulse of 640 insec duration. The gap in each trace indicates the suspension in phase tracking that occurred when the calcium current was evoked. Calcium currents for each response are shown above the capacitance trace. Depolarizations also evoked a conductance change (small capital $G$ below $A$ ), which apparently mirrors the Cm jumps. This cell was bathed in extracellular saline containing reduced chloride $(75 \mathrm{~mm})$, but the conductance changes are similar to those recorded in cells bathed in normal saline. Independent estimates of membrane conductance were simultaneously obtained during each trace by giving small (20 mV) hyperpolarizing and depolarizing voltage pulses to mimic the changes in voltage that occur during the sinusoidal voltage input of phase tracking. Conductance was calculated from the current flowing after decay of uncompensated capacitance, $G=I / V$, and values obtained every 1 sec from hyperpolarizing $\left(G_{\mathrm{h}}\right)$ and depolarizing $\left(G_{\mathrm{d}}\right)$ pulses are shown on the same time scale, below the conductance traces from phase tracking. These measurements confirmed that a conductance change occurred after step depolarizations, which increased with increasing calcium entry, and was symmetrical for hyperpolarizing and depolarizing voltage steps. The increase was maximal $(\sim 0.25 \mathrm{nS})$ at durations of $80 \mathrm{msec}$, however, indicating that the prolonged displacement of the $G$ trace after a $640 \mathrm{msec}$ pulse is not attributable to changes in membrane conductance but probably represents an increase in access resistance. Cell N012702.

\section{Changing the flux per channel: external calcium concentration}

We examined the effect of changing the rate of calcium influx on large dense-cored vesicle exocytosis without altering other parameters of calcium entry, such as number of open channels or pulse duration, by perfusing single cells with various external calcium concentrations. In the experiment shown in Figure 2, cxocytosis ( $\Delta \mathrm{Cm}$, in $\mathrm{fF}$ ) evoked by single depolarizing pulses in the presence of different external calcium concentrations $(0.25-5.0 \mathrm{~mm})$ was plotted as a function of integrated calcium entry, in number of ions. The data were fit by the equation $\Delta \mathrm{Cm}=g \times\left(\Sigma \mathrm{Ca}^{2+}\right.$ ions) ${ }^{X}$. In this cell, $g=0.3$ and $X=1.9$ (Fig. $2 A$ ), suggesting that exocytosis of large dense-core vesicles is related to calcium entry with a power $\leq 2$. We also plotted $\Delta \mathrm{Cm}$ versus total calcium ions on logarithmic coordinates and found that the slope was 1.6 (Fig. 2B).

\section{Flux per channel versus number of channels: test potential}

For small depolarizations, the driving force for calcium entry is large, but few channels are open. For larger depolarizations, the number of channels that are opened increases, but the driving force decreases. Thus the influence of a few channels, passing a large number of calcium ions, can be compared with that of many channels passing few calcium ions.
We found in perforated-patch recordings that large densecored vesicle exocytosis was related to total calcium entry, regardless of test potential (Fig. $3 A$ ). Exocytosis was evoked by a 160 msec depolarization from a holding potential of $-90 \mathrm{mV}$ to the indicated test potential (Fig. 3B). Equivalent calcium entry, for potentials more positive than the peak of the current-voltage relationship (Fig. 3A, filled squares), or more negative (Fig. $3 A$, open squares), evoked the same increase in capacitance up to potentials of $+60 \mathrm{mV}$. At more positive potentials, small capacitance increases were evoked (5-10 fF) (Fig. 3B, top), but calcium influx is obscured by the presence of an outward current (Fig. 3B, bottom). Data from all test potentials (excluding pulses that evoked outward current) were fit by the equation $\Delta \mathrm{Cm}=0.33 \times$ $\left(\Sigma \mathrm{Ca}^{2+} \text { ions }\right)^{1.9}$.

The remarkable similarity in the quantitative relationship between $\Delta \mathrm{Cm}$ and calcium entry for experiments in which test potential was changed and for experiments using different calcium concentrations indicates that exocytosis of large dense-cored vesicles is relatively independent of ion flux or the number of channels opened, if the total number of calcium ions is equivalent.

\section{Submembrane calcium concentration versus cumulative calcium entry: duration}

If exocytosis of large dense-cored vesicles depends on the integral of the calcium current, the amount of calcium entry can be altered 
Figure 2. Exocytosis of large dense-cored vesicles is a second order function of integrated calcium entry. $A$, Individual $\mathrm{Cm}$ jumps in response to $160 \mathrm{msec}$ depolarizations to $+20 \mathrm{mV}$, from a holding potential of $-90 \mathrm{mV}$. Single depolarizations were applied every 90 sec; several depolarizations of $40 \mathrm{msec}$ duration were included between each $160 \mathrm{msec}$ pulse to discharge any facilitatory effects of prolonged calcium cntry (data not shown; see Results). Calcium entry was varied by external perfusion of different concentrations of $\mathrm{CaCl}_{2}$ in the following sequence: $2 \mathrm{~mm}, 0.5 \mathrm{~ms}, 0.25 \mathrm{~mm}, 2 \mathrm{~ms}$, and $5 \mathrm{~mm}$ (magnesium concentration always 1 $\mathrm{mM}$ ). Some responses were recorded before a switch in concentration was complete, resulting in a graded range of calcium current integrals. Data were fit to the equation, $Y(\Delta \mathrm{Cm})=g \times\left(\mathrm{Ca}^{2+} \text { ions }\right)^{X}$ with $g=0.29$, and a power of 1.9 ; the curve was constrained to pass through $Y=0$ at 0 calcium entry. $B$, Plot of $\log (\Delta \mathrm{Cm})$ versus $\log \left(\sum \mathrm{Ca}^{2-}\right.$ ions). Slope $(1.6 ; r=0.96)$ is slightly less than exponential fit in $A$, probably because the apparent linear fit to the data in $B$ was not constrained to pass through the origin. Cell N011302.
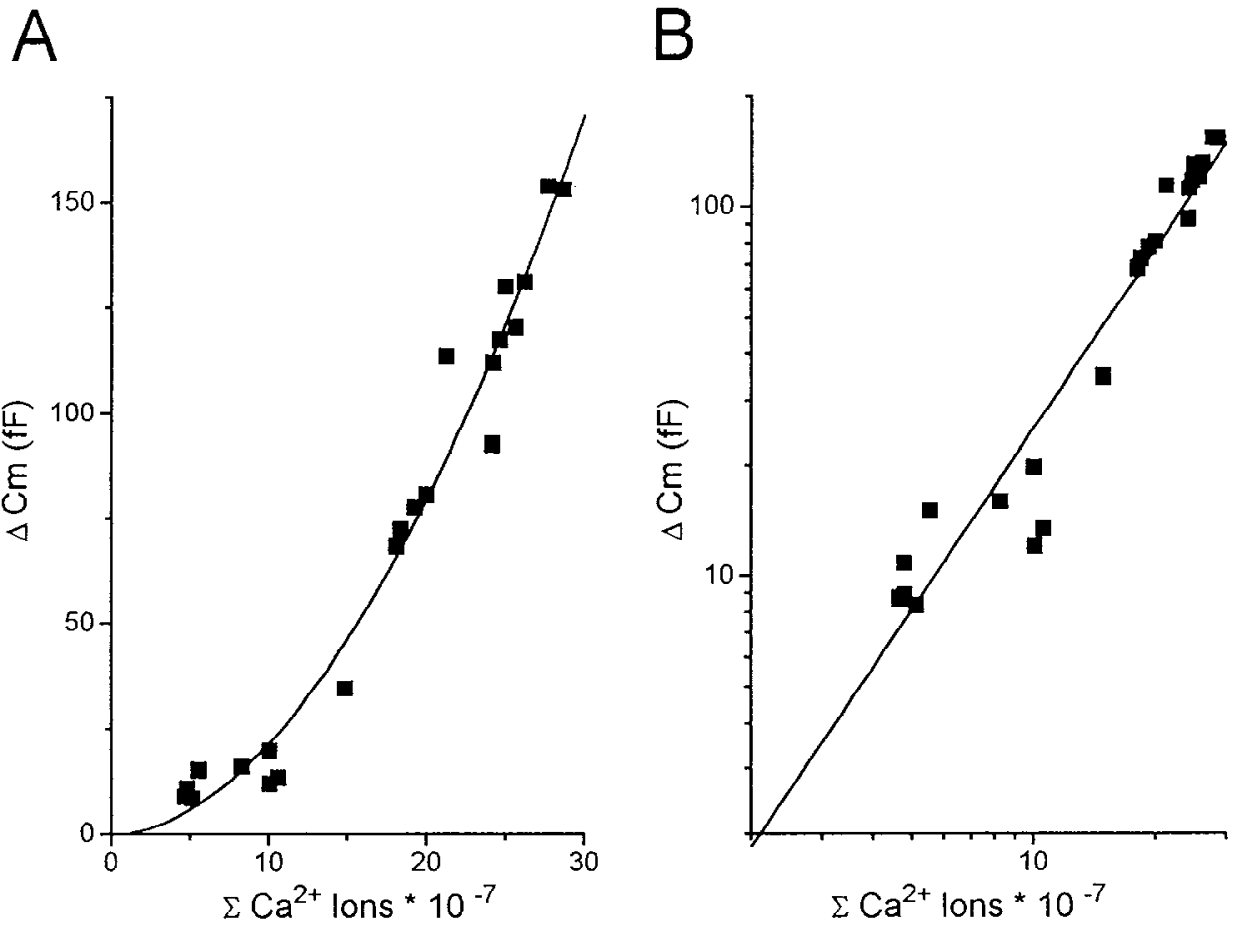

over a wide range simply by changing the duration of the stimulating pulse. On the other hand, if exocytosis depends on submembrane calcium concentration, increasing duration will be much less effective than protocols that increase the amplitude of the calcium current (Nowycky and Pinter, 1993; Roberts, 1994).

The capacitance traces shown in Figure $1 A-D$ demonstrate exocytotic responses to pulses of increasing length. These responses, as well as responses croked by scveral intermediatc durations, are plotted as a function of total calcium entry, in number of ions, in Figure $4 A$. The data were fit by the equation $\Delta \mathrm{Cm}=g \times\left(\sum \mathrm{Ca}^{2+}\right.$ ions) ${ }^{X}$, where $g=1.25$ and $X=1.3$ (Fig. $4 A$ ). The slope on logarithmic coordinates was 0.9 (Fig. $4 B$ ).

With increasing duration, we found no indication of depletion or limitation in the amount of release. The only limitation was the inactivation of the calcium current, which was almost complete by the end of $640 \mathrm{msec}$ (Fig. 1D). Further illustration that release could be maintained for many milliseconds is shown in Figurc $4 C$. For each duration, the amount of exocytosis was normalized to the amount of calcium entry. The efficacy of calcium-secretion coupling remains the same for pulses ranging in length from 10 to $160 \mathrm{msec}$. At long durations, rather than a decrease in coupling efficacy that might reflect depletion or depression, there was a significant enhancement. The anomalously large ratio of $\Delta \mathrm{Cm}$ per calcium ion for $5 \mathrm{msec}$ pulses is attributable to a lack of null responses or failures, despite a small amount of calcium entry. If the capacitance increases in response to $5 \mathrm{msec}$ depolarizations are the result of one to two large dense-cored vesicles fusing with the plasma membrane, it seems surprising that a pulse rarely failed to evoke a response. Cm jumps evoked by $5 \mathrm{msec}$ pulses may reflect the fusion of a larger population of small vesicles or contamination from sources other than membrane fusion, such as channel gating charges (Horrigan and Bookman, 1994).

In Figure 5, calcium entry was varied in a single cell by changing duration (filled squares; $10-320 \mathrm{msec}$ ) or by perfusing with different external calcium concentrations (open squares; 0.5-5.0 mM). $\Delta \mathrm{Cm}$ versus integrated calcium entry was plotted on linear (Fig.
$5 A$ ) or logarithmic (Fig. $5 B$ ) coordinates, and in both cases data from the two protocols overlap completely. The combined data were fit by the equation $\Delta \mathrm{Cm}=0.23 \times\left(\Sigma \mathrm{Ca}^{2+} \text { ions }\right)^{1.8}$. These data confirm that in bovine adrenal chromaffin cells, the secretory apparatus seems to respond to total calcium entry, regardless of flux or peak submembrane $\left[\mathrm{Ca}^{21}\right]$, because the amount of exocytosis evoked by a small amplitude current maintained for a long duration is comparable to the amount cvoked by a large amplitude but brief current.

\section{Number and type of calcium channels: calcium channel blockers}

Three calcium channel subtypes have been identified in bovine adrenal chromaffin cells: $\mathrm{N}$-type ( $\omega$-conotoxin-sensitive), P-type ( $\omega$-agatoxin-sensitive), and L-type (dihydropyridine-sensitive) (Artalejo et al., 1994). We examined whether secretion evoked by single depolarizations was coupled more tightly to one particular calcium channel type.

In Figure $6 A$, we compared responses evoked by depolarizations ranging in duration from 10 to $320 \mathrm{msec}$, before (filled squares) and after (open squares) application of $1 \mu \mathrm{M} \omega$-conotoxin GVIA. The current sensitive to $\omega$-conotoxin shows inactivation during a $40 \mathrm{msec}$ pulse and is completely inactivated by the end of a $320 \mathrm{msec}$ pulse (Fig. 6B). Despite the fact that inhibition of $\mathrm{N}$-channels affects the initial peak far more than later in the pulse, exocytosis after $\omega$-conotoxin falls on the same curve generated by different pulse durations under control conditions. The combined data were fit by the equation $\Delta \mathrm{Cm}=1.3 \times\left(\mathrm{CCa}^{2-} \text { ions }\right)^{1.4}$, virtually the same equation found in experiments in which duration alone was altered (Fig. 4).

Bovine chromaffin cells are also sensitive to the P-type calcium channel antagonist $\omega$-agatoxin IVA. Calcium currents were not inhibited by concentrations of agatoxin that are reported to specifically block P-type channels (10-100 nM) (Mintz et al., 1992a,b) but were reduced at concentrations that inhibit both P-type and a newly described subtype, the Q-channel (Sather et al., 1993; 


\section{A $\quad$ B}
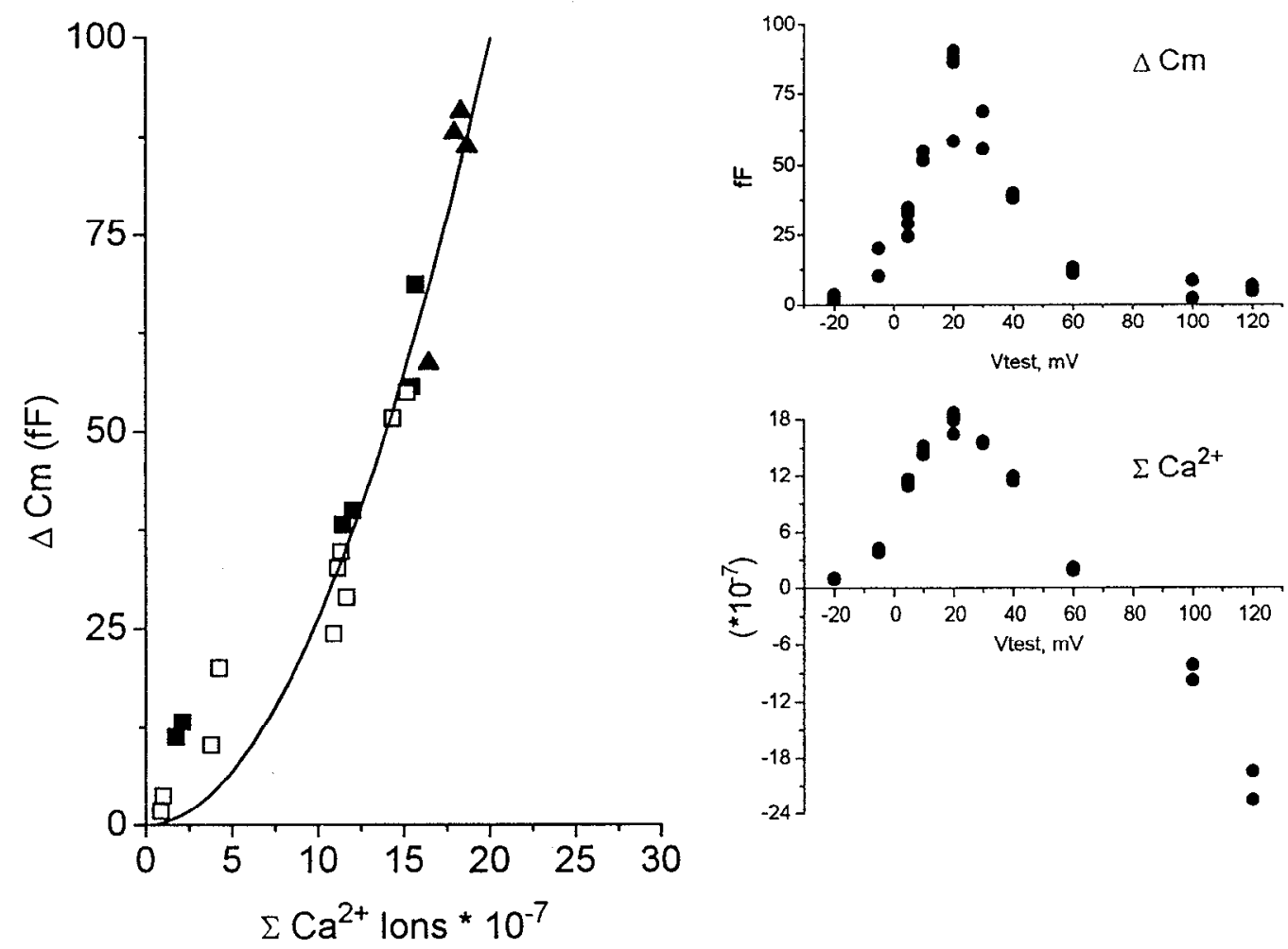

Figure 3. Exocytosis of large dense-cored vesicles is a function of integrated calcium entry, regardless of calcium channel flux or number of calcium channels. $A$, Individual $\Delta \mathrm{Cm}$ responses evoked by $160 \mathrm{msec}$ depolarizations to different test potentials. Equivalent integrals of calcium entry elicited the same $\mathrm{Cm}$ jumps, whether or not they were the result of a few channels carrying a large calcium flux (potentials negative to +20 , filled squares) or of many channels with little flux (potentials positive to +20 , open squares); $\mathrm{Cm}$ jumps in response to depolarizations to $+20 \mathrm{mV}$ are shown as filled triangles. Curve: $\Delta \mathrm{Cm}=0.33 \times\left(\Sigma \mathrm{Ca}^{2+} \text { ions }\right)^{1.9} \cdot B, \Delta \mathrm{Cm}(t o p)$ shows a bell-shaped relationship with test potential that parallels that of cumulative calcium entry $($ bottom $)$. An outward current develops at very positive potentials. This current probably contributes some error to measurements of inward calcium entry at vollages $>+40 \mathrm{mV}$; note that the calculation of number of ions is based on a divalent ionic species and will be in error for an outward current that is probably carried by $\mathrm{K}^{+}$ions. $\Delta \mathrm{Cm}$ responses for negative current integrals, i.e., at $V_{\text {tcst }}>+60 \mathrm{mV}$ are not shown in $A$. Cell $\mathrm{K} 122001$.

Wheeler et al., 1994; Randall and Tsien, 1995). Q-type calcium currents in ccrebellar granule cells show inactivation during relatively brief depolarizations (Randall and Tsien, 1995). The current inhibited by $\omega$-agatoxin in bovine adrenal chromaffin cells, however, was largely noninactivating (see Fig. $7 B$, Difference current).

Figure $7 A$ shows an experiment in which the duration of the stimulating pulse was kept constant $(160 \mathrm{msec})$, but calcium entry was altered by inhibiting first the $\omega$-agaloxin-sensitive calcium current and then the $\omega$-conotoxin sensitive current. The combined effect of the two toxins almost completely abolished inward current in response to a depolarization. Therefore, exocytosis was first evoked by calcium entry through both channel subtypes (Fig. $7 A, 1)$, then through only N-type (2), then through neither channel (3), and finally through $\mathrm{P} / \mathrm{Q}$-type calcium channels by relieving the $\omega$-agatoxin block with a depolarizing prepulse (4). Although the inhibitors changed the kinetics of calcium entry during a depolarization from completely inactivating to only slightly inactivating (Fig. $7 B$ ), the amount of exocytosis was simply related to the integral of the calcium current, with the equation $\Delta \mathrm{Cm}=0.9$ $\times\left(\Sigma \mathrm{Ca}^{2+} \text { ions }\right)^{1.5}$.

We found that under "resting" conditions, the L-channel sub- type makes up only a minor component in the overall current amplitude. Application of the dihydropyridine antagonists nifedipine and nisoldipine had little effect on calcium channel current, and as shown in Figure $7 B, \mathrm{~N}$ - and $\mathrm{P} / \mathrm{O}$-type channels are responsible for almost all of the inward current.

Figure 8 shows $\Delta \mathrm{Cm}$ plotted as a function of integrated calcium entry, for pulse durations from 10 to $640 \mathrm{msec}$, before (filled squares) and after (open squares) application of the $\mathrm{D}_{1}$ agonist SKF-38393, which is reported to induce the facilitation channel, an L-type channel, in bovine adrenal chromaffin cells (Artalejo et al., 1990, 1994). Application of SKF-38393 slightly increased peak current amplitude (Fig. 8, inset), an effect that could be reversed by application of $5 \mu \mathrm{m}$ nisoldipine, indicating that the agonist did indeed induce facilitation current. SKF-38393 seemed to enhance calcium current inactivation, and there was no net increase in calcium entry for longer duration pulses. The change in kinetics of the voltage-clamped calcium current after SKF-38393 application may be caused by inhibition of P/Q-type channels (Surmeier et al., 1995) at the same time that calcium entry through L-type channels is augmented. Despite a possible shift in calcium entry from primarily $\mathrm{N}$ - and $\mathrm{P} / \mathrm{Q}$-type channels to L-type channels, $\mathrm{Cm}$ jumps evoked in the presence of the agonist were virtually identical to 
Figure 4. Amount of exocytosis increases as a function of cumulative calcium entry, not time. $A$, Individual $\Delta \mathrm{Cm}$ jumps in response to $5,10,20,40,160$, 320 , and 640 insec pulses are shown plotted versus integrated calcium entry. Same cell as shown in Figure 1. Data were fit to the equation $\Delta \mathrm{Cm}=g \times$ $\left(\Sigma \mathrm{Ca}^{2+} \text { ions }\right)^{x}$, with $\mathrm{g}=1.25$ and a power of 1.3. B, Plot of $\log (\Delta \mathrm{Cm})$ versus $\log \left(\Sigma \mathrm{Ca}^{2+}\right.$ ions $)$, slope $=0.9(r=0.89)$. $C$, Calcium-secretion coupling $(\Delta \mathrm{Cm} /$ $\Sigma \mathrm{Ca}^{2+}$ entry) was remarkably consistent for different duration pulses. Data were pooled from eight experiments in which duration was varied between 5 and 640 $\mathrm{msec}$. Compared with the coupling ratio for $40 \mathrm{msec}$ duration pulses, only the ratios for 5, 320, and 640 msec pulses are significantly different $(p<0.05)$. The large ratio for $5 \mathrm{msec}$ durations is not well understood and may be attributable to a pool of small vesicles or a nonvesicular source of capacitance. For long duration pulses, the increase in calciumsecretion coupling efficacy strongly suggests that available vesicles were'not depleted at these time points.
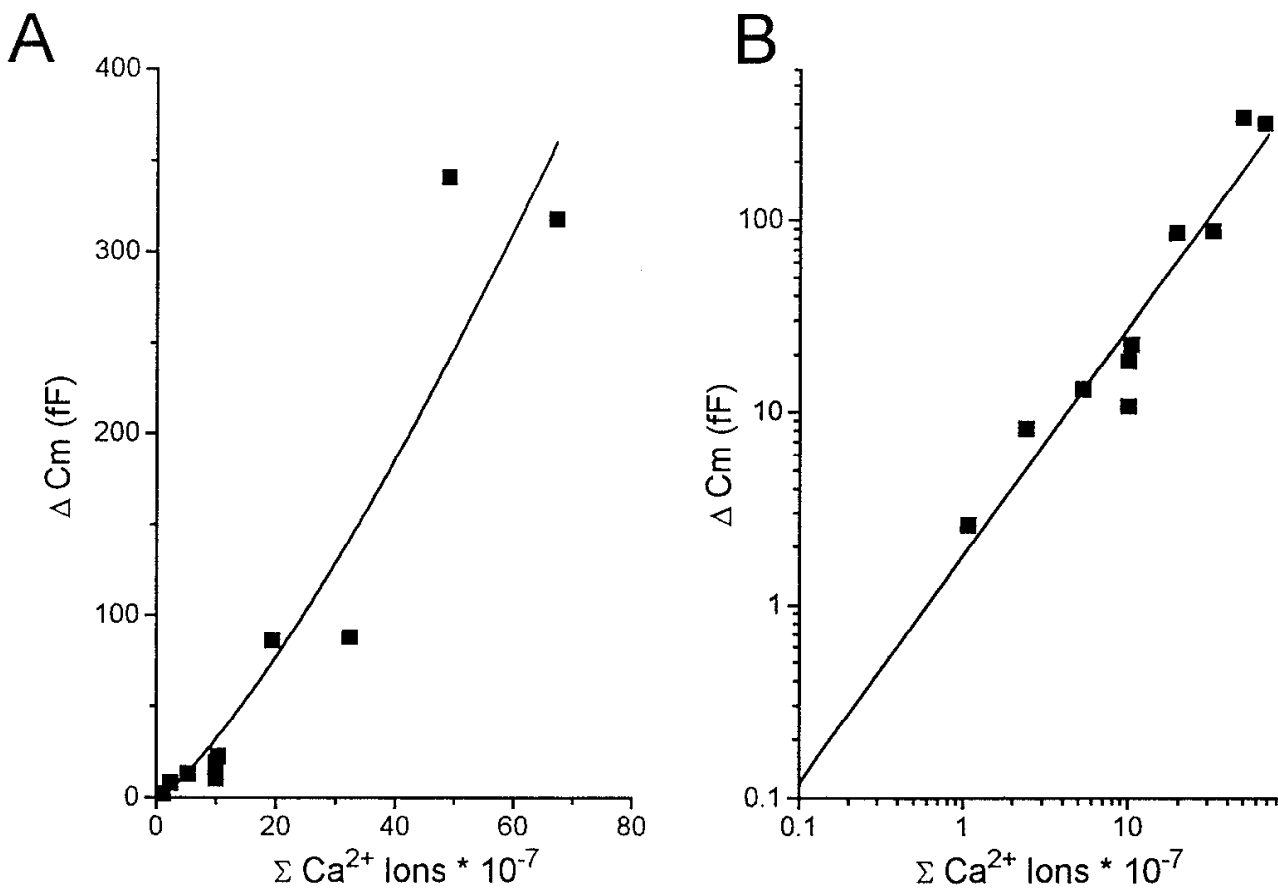

C

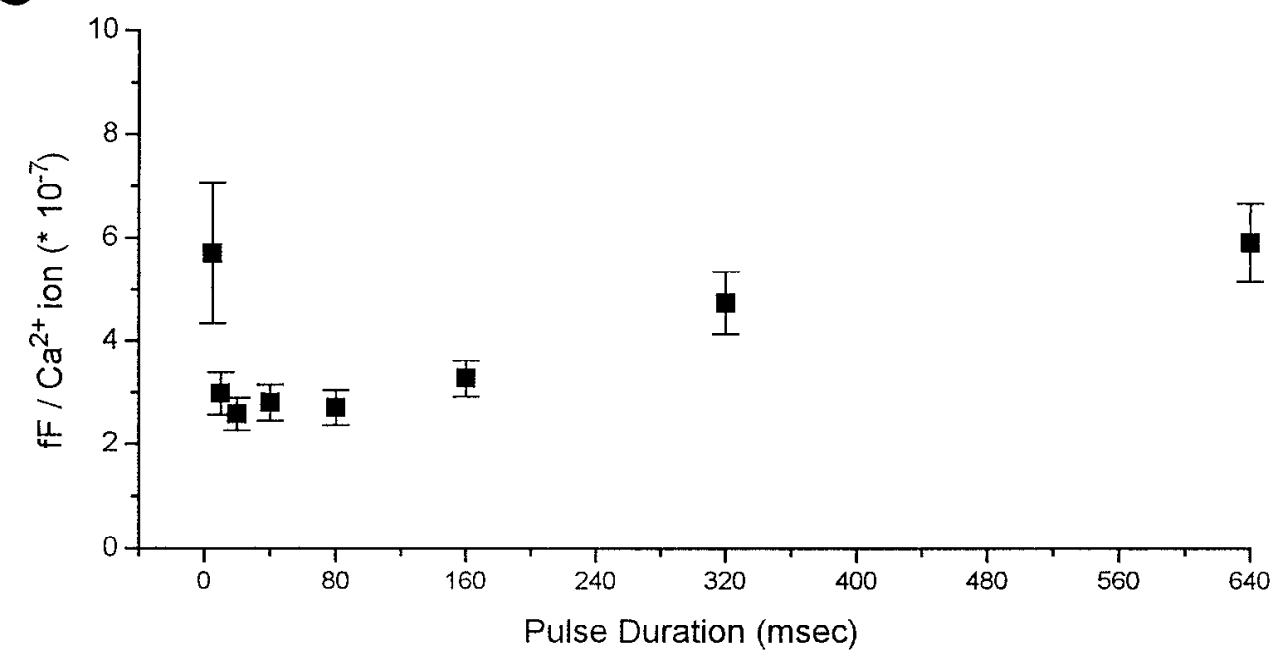

control responses, and the combined data were fit by the equation $\Delta \mathrm{Cm}=0.24 \times\left(\Sigma \mathrm{Ca}^{2+} \text { ions }\right)^{1.8}$.

After prolonged calcium entry, facilitation of $40 \mathrm{msec}$ pulses seemed to be enhanced in the presence of SKF-38393 (data not shown). These results suggest that the large exocytosis evoked by calcium entry through L-type calcium channels during trains of depolarizations (Artalejo et al., 1994) or potassium superfusion (Lopez et al., 1994) is the result of a unique coupling between this channel and mechanisms of stimulus-dependent facilitation.

Table 1 summarizes the results obtained from 26 cells. Each cell name indicates a different cell; for several cells, more than one type of experiment (e.g., duration, IV) was performed. 'I'he proportionality factor, " $g$," and "power" for the transfer function were obtained from a curve-fitting routinc as described in Matcrials and Methods. The "slope" was obtained by plotting the same data on logarithmic coordinates, and the $R$ value is from the apparent linear fits (see Materials and Methods). Despite some variability in the parameters across cells and between protocols, there was consistently a strong correlation $(R>0.8)$ between the amount of exocytosis and integrated calcium entry.

\section{DISCUSSION}

\section{Analysis of the calcium dependence of large dense-cored vesicle exocytosis in perforated-patch recordings}

The stability afforded by perforated-patch recordings allowed us to examine the effect of altering the amount and parameters of calcium entry on the exocytotic response in bovine adrenal chromaffin cells to an extent that was not possible previously because of the decay of secretory responsiveness during wholecell recordings (Augustine and Neher, 1992; Seward and Nowycky, 1996). Under stringent experimental conditions, in which exocytosis was evoked by single step depolarizations and responses occurring after periods of large calcium influx were not included in analyses, the secretory response to single step 

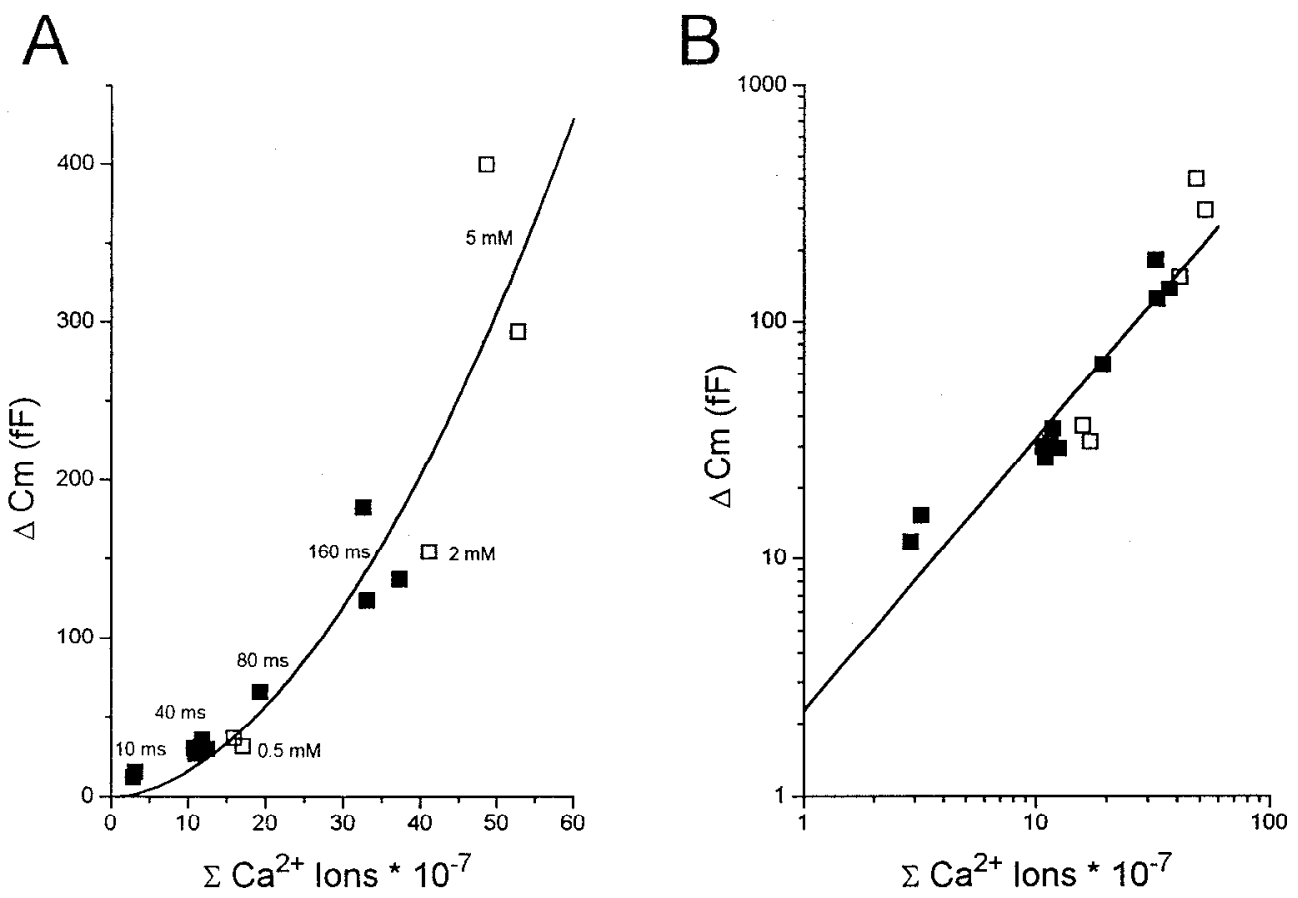

Figure 5. Exocytosis is a function of integrated calcium entry, regardless of flux or duration: changing external calcium concentration and pulse length in a single cell. Depolarizing pulses to $+20 \mathrm{mV}$ (holding potential, $-90 \mathrm{mV}$ ) for 320 msec were used to stimulate exocytosis in a cell bathed in $0.5 \mathrm{~mm}, 2 \mathrm{~mm}$, and $5 \mathrm{~mm}$ external $\mathrm{CaCl}_{2}$ (open squares). In addition, at $5 \mathrm{~mm}$ external $\mathrm{CaCl}_{2}$, duration of the depolarizing pulse was varied between 10 and $320 \mathrm{msec}$ (filled squares). The data were fit by the equation $\Delta \mathrm{Cm}=$ $0.23 \times\left(\Sigma \mathrm{Ca}^{2+} \text { ions }\right)^{1.8}(A)$ or by apparent linear fit on logarithmic coordinates, with a slope of $1.15(r=0.94)(B)$. Subset - Duration $\left(5 \mathrm{mM} \mathrm{CaCl}_{2}\right)$
- External $\left[\mathrm{Ca}^{2+}\right](320 \mathrm{~ms}$ duration $)$ of data from cell N021602.

depolarizations was consistently related to integrated calcium entry.

When we changed the rate of calcium influx by applying different external calcium concentrations, we found that release was related to integrated calcium entry raised to a power $<2$. We used the voltage dependence of calcium channels to alter the number of open channels and single channel flux and found again that the amount of exocytosis depended only on the total number of calcium ions. We changed duration and found that exocytosis was related to the integral of calcium ion flux for pulse durations between 10 and $640 \mathrm{msec}$. Inhibition of either $\mathrm{N}$ - or $\mathrm{P} / \mathrm{Q}$-type calcium channels, or activation of L-type calcium channels, altered exocytosis by an amount that could be predicted from the total number of calcium ions.

From these results, we conclude that secretion of large dense-cored vesicles is not strictly dependent on a high calcium concentration, which occurs near the opening of a single calcium channel ("nanodomain," Schweizer et al., 1995) or that can be achieved by the simultaneous opening of closely spaced calcium channels during a large depolarization ("microdomain," Llinas et a1., 1981, 1992). Exocylosis of large densecored vesicles is also not related to global calcium elevations, because the quantitative relationship was the same for pulse durations over a wide range, even though $\left[\mathrm{Ca}^{2+}\right]_{i}$ would not equilibrate throughout the cell during brief pulses. In addition, global $\left[\mathrm{Ca}^{2+}\right]_{\mathrm{i}}$ increases are maintained for several seconds after depolarizations (Augustine and Neher, 1992; Neher and Augustine, 1992), but we found that $\mathrm{Cm}$ increases terminated shortly after the pulse. Finally, the amount of exocytosis is not a strict function of the calcium concentration in a "shell" domain near the membrane. Shell models predict that after a step depolarization, submembrane calcium concentration will reach a high value within milliseconds and increase only slowly thereafter (Sala and Hernandez-Cruz, 1990; Nowycky and Pin- ter, 1993). In contrast, altering the amplitude of the current should cause a proportional change in the peak submembrane calcium concentration (Nowycky and Pinter, 1993). We found that the relationship between integrated calcium entry and release was remarkably consistent for a wide variety of calcium entry parameters, which would produce quite different spatial and temporal profiles of $\left[\mathrm{Ca}^{2+}\right]_{i}$ near the membrane. Thus, exocytosis seems to be related to the integral of the calcium current, which reflects both submembrane $\left[\mathrm{Ca}^{2+}\right]_{i}$ and the amount of time that it is raised, rather than concentration alone.

\section{Can calcium-dependent exocytosis of large dense- cored vesicles be described by the law of mass action?}

Current models of calcium-secretion coupling for large densecored vesicles treat exocytosis as a series of chemical reactions, relying on the law of mass action for a quantitative description (Thomas et al., 1993b; Heinemann et al., 1994) by analogy with fast synaptic transmission (Jenkinson, 1957; Dodge and Rahamimoff, 1967). According to the law of mass action, the rate of exocytosis (fF/sec) should be related to $\left[\mathrm{Ca}^{2+}\right]_{i}^{n}$, where $n$ represents the number of calcium ions that must bind to the receptor to initiate fusion. At the neuromuscular junction (Dodge and Rahamimoff, 1967; Cooke et al., 1973; Cull-Candy et al., 1980; Dudel, 1981) and squid giant synapse (Katz and Miledi, 1970; Augustine and Charlton, 1986; Stanley, 1986), the postsynaptic response varies as the third to fourth power of external calcium concentration. Results from flash photolysis experiments suggest that the rate of release of at least one kinetic component of large dense-cored vesicles is a high order function of intracellular calcium concentration, although the relationship between $\left[\mathrm{Ca}^{2+}\right]_{\mathrm{i}}$ and exocytotic rate is limited by a calcium-independent fusion step (Heinemann et al., 1994). 


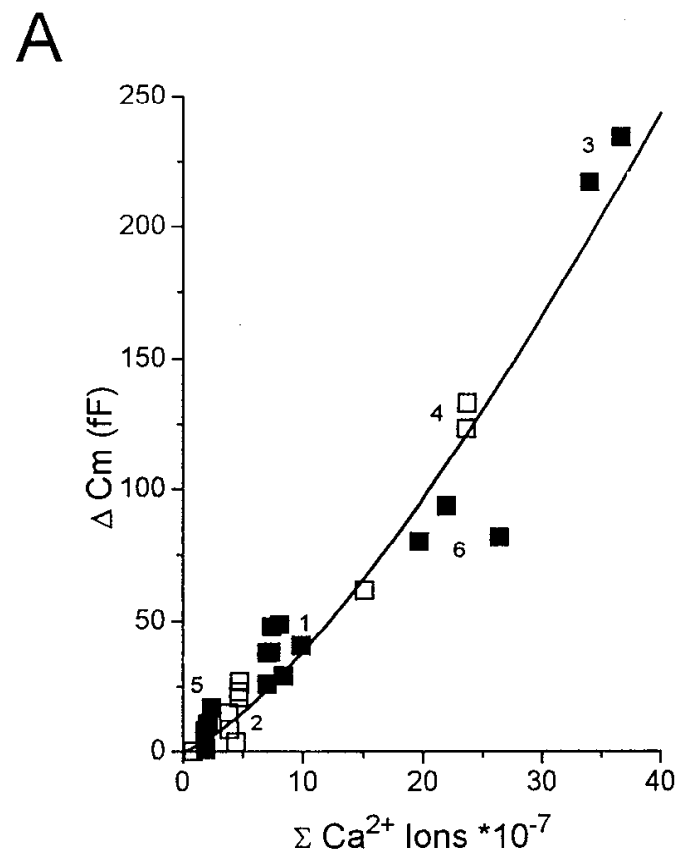

B

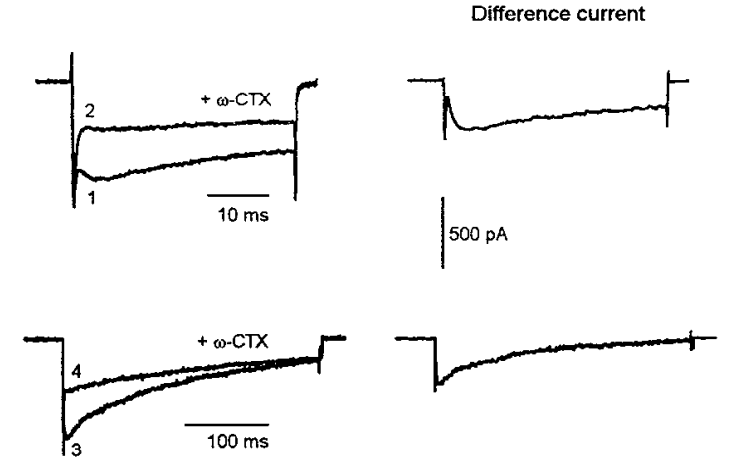

Figure 6. Exocytosis after inhibition of N-type calcium channels by $\omega$-conotoxin remains a function of integrated calcium entry. $A, \Delta \mathrm{Cm}$ in response to $10,40,160$, and $320 \mathrm{msec}$ depolarizations to $+20 \mathrm{mV}$ before (filled squares) and after (open squares) perfusion of $1 \mu \mathrm{M} \omega$-conotoxin GVIA. Exocytosis evoked by $40 \mathrm{msec}$ pulses $(1,2)$ and $320 \mathrm{msec}$ pulses $(3,4)$ is reduced by an amount predicted by the decrease in $\Sigma \mathrm{Ca}^{2+}$ entry, on the basis of control responses evoked by $10 \mathrm{msec}(5)$ and $160 \mathrm{msec}$ duration pulses $(6)$. Curve: $\Delta \mathrm{Cm}=1.3 \times\left(\Sigma \mathrm{Ca}^{2+} \text { ions }\right)^{1.4}$. B: Left, Calcium currents corresponding to the Cm jumps shown in $A$. Right, Difference currents, obtained by subtracting 2 from 1 , top, and 4 from 3 , bottom, demonstrate that an inactivating current is blocked by $1 \mu \mathrm{M} \omega$-conotoxin. Inhibition of $\mathrm{N}$-type calcium current has almost no effect on the current remaining at the end of a 320 msec pulse. Cell N021601.

If time is included in the rate expression obtained from the law of mass action, the total amount of secretion, $\Delta \mathrm{Cm}$, can be expressed as:

$$
\Delta \mathrm{Cm} \propto\left[\mathrm{Ca}^{2+}\right]^{n} \times \text { time. }
$$

According to the law of mass action, protocols that increase the duration of $\mathrm{Ca}^{2+}$ entry and protocols that increase $\mathrm{Ca}^{2+}$ flux will produce equivalent effects on the amount of exocytosis only if $n=$ 1. In the present study, we found that whether stimulus protocols increased submembrane calcium concentration or prolonged the duration of calcium entry, secretion under conditions of minimal stimulation was always expressed as a simple transfer function of the form:

$$
\Delta \mathrm{Cm}=g \times\left(\Sigma \mathrm{Ca}^{2+} \text { ions }\right)^{x}
$$

where $g$ is a proportionality factor, $X$ varied between 0.9 and 2.7 (see Table 1), and $\Sigma \mathrm{Ca}^{2+}$ ions, the integral of the calcium current, reflects both the flux of calcium and the amount of time that calcium entry continues. Thus, in a single cell, a small-amplitude, prolonged depolarization $(320 \mathrm{msec})$ evoked the same amount of exocytosis as a brief duration ( $40 \mathrm{msec}$ ), large-amplitude current (see Fig. 5). Our results suggest that either $n=1$ (exocytosis of large dense-cored vesicles is not a high-order function of calcium concentration) or the law of mass action is not an adequate descriptor of exocytosis evoked by calcium influx through voltagcgated channels.

It is unlikely that a simple law of mass action equation can be devised that describes the calcium dependence of depolarizationevoked exocytosis. During voltage-gated calcium entry, calcium concentration changes rapidly, nonuniformly, and transiently. Rate equations become quite complex if the reaction is not at steady state or equilibrium (Gentry et al., 1995). Distinct vesicular pools may be depleting at different total calcium entry levels, so the amount of exocytosis will be limited by pool size, not calcium concentration (Heinemann et al., 1994). Most importantly, more than one calcium-dependent reaction may be involved in exocytosis of large dense-cored vesicles. The individual reactions may have different calcium dependencies, and some of the reactions may be irreversible.

Our findings demonstrate that the relationship between transient and inhomogenous changes in submembrane calcium concentration, and calcium-dependent reactions of unknown number and properties, can be well-approximated by a simple transfer function of summed calcium entry. Because there is no way to relate the time integral of the calcium current to calcium concentration at the relevant calcium-sensing sites responsible for exocytosis, the transfer function is not an expression of the law of mass action. One consequence of not using the law of mass action is that the power included in the empirically determined transfer function, which was on average 1.5 (see Table 1), cannot be used to conclude that one to two calcium ions must bind in order to initiate fusion, nor does it rule out a larger number of binding sites. Furthermore, the equilibrium properties of a calcium sensor such as affinity are not critical during nonuniform and brief increases in intracellular calcium. Instead, as calcium ions enter the cell through calcium channel pores, there is some finite, and perhaps modifiable, probability that a calcium ion (or multiple calcium ions) will interact with 
Table 1. Summary of quantitative data for $\Delta \mathrm{Cm}$ versus integrated calcium entry

\begin{tabular}{|c|c|c|c|c|c|c|}
\hline Cell & Experiment & Range & $g$ & Power & Slope & $R$ value \\
\hline K120205 & Duration & $5-1000 \mathrm{msec}$ & 5.253 & 0.921 & 0.997 & 0.979 \\
\hline $\mathrm{K} 120802$ & Duration & $20-320 \mathrm{msec}$ & 0.707 & 1.523 & 1.394 & 0.962 \\
\hline K120803 & Duration & $10-1000 \mathrm{msec}$ & 0.753 & 1.489 & 1.392 & 0.943 \\
\hline K122903 & Duration & $10-1000 \mathrm{msec}$ & 0.031 & 2.581 & 1.58 & 0.981 \\
\hline N031505 & Duration & $10-320 \mathrm{msec}$ & 0.538 & 1.562 & 1.383 & 0.942 \\
\hline N031701 & Duration & $5-640 \mathrm{msec}$ & 15.18 & 0.609 & 0.565 & 0.787 \\
\hline N040502 & Duration & $10-320 \mathrm{msec}$ & 2.447 & 1.01 & 0.856 & 0.937 \\
\hline N012507 & Dur/luw $\mathrm{Cl}^{-}$ & $5-1000$ insec & 1.496 & 1.338 & 0.916 & 0.922 \\
\hline N012702 & Dur/low $\mathrm{Cl}^{-}$ & $5-640 \mathrm{msec}$ & 1.251 & 1.343 & 0.944 & 0.893 \\
\hline N013001 & Dur/low $\mathrm{Cl}^{-}$ & $10-640 \mathrm{msec}$ & 2.327 & 1.217 & 1.091 & 0.981 \\
\hline N020302 & Dur/aga & $10-320 \mathrm{msec}$ & 0.123 & 2.05 & 0.993 & 0.866 \\
\hline N020401 & Dur/aga & $10-320 \mathrm{msec}$ & 0.258 & 2.02 & 1.103 & 0.770 \\
\hline N021702 & Dur/aga & $10-320 \mathrm{msec}$ & 0.928 & 1.48 & 1.29 & 0.933 \\
\hline No32903 & Dur/aga & $10-320 \mathrm{msec}$ & 10.3 & 0.699 & 0.854 & 0.777 \\
\hline N040101 & Dur/aga & $40-320 \mathrm{msec}$ & 2.242 & 1.114 & 1.02 & 0.903 \\
\hline N012001 & Dur/ctx & $40-160 \mathrm{msec}$ & 1.954 & 1.095 & 1.256 & 0.841 \\
\hline N012002 & Dur/ctx & $40-160 \mathrm{msec}$ & 0.993 & 1.42 & 1.312 & 0.969 \\
\hline N021601 & Dur/ctx & $10-320 \mathrm{msec}$ & 1.335 & 1.407 & 1.484 & 0.886 \\
\hline N031505 & aga/ctx & $160 \mathrm{msec}$ & 0.875 & 1.459 & 1.006 & 0.978 \\
\hline N012701 & Dur/nil & $20-160$ musec & 0.566 & 1.611 & 1.479 & 0.957 \\
\hline N021204 & Dur/nif & $10-320 \mathrm{msec}$ & 0.015 & 2.67 & 1.64 & 0.919 \\
\hline N032401 & Dur/skf/nis & $10-640 \mathrm{msec}$ & 0.242 & 1.792 & 1.011 & 0.849 \\
\hline N032402 & Dur/skf & $5-320 \mathrm{msec}$ & 1.175 & 1.303 & 0.794 & 0.894 \\
\hline K122001 & IV & -20 to $+60 \mathrm{mV}$ & 0.331 & 1.907 & 1.005 & 0.953 \\
\hline K122903 & IV & -20 to $+60 \mathrm{mV}$ & 3.083 & 1.042 & 1.109 & 0.988 \\
\hline N012002 & $\operatorname{ctx} / \mathrm{IV}$ & -10 to $+50 \mathrm{mV}$ & 5.729 & 0.91 & 1.312 & 0.969 \\
\hline N011102 & Ext $\mathrm{Ca}$ & $0.5-5 \mathrm{~mm}$ & 1.081 & 1.514 & 1.871 & 0.968 \\
\hline N011102 & Ext $\mathrm{Ca} / 40 \mathrm{msec}$ & $0.5-5 \mathrm{mM}$ & 1.822 & 1.319 & 1.386 & 0.818 \\
\hline N011301 & Ext $\mathrm{Ca}$ & $0.25-2 \mathrm{~mm}$ & 0.064 & 2.175 & 1.494 & 0.943 \\
\hline N011302 & Ext $\mathrm{Ca}$ & $0.25-5 \mathrm{~mm}$ & 0.286 & 1.879 & 1.622 & 0.965 \\
\hline N011302 & Ext $\mathrm{Ca} / 40 \mathrm{msec}$ & $0.25-5 \mathrm{~mm}$ & 1.936 & 1.451 & 1.25 & 0.967 \\
\hline N021602 & Dur/Ext Ca & $10-320 / 0.5-5$ & 0.317 & 1.759 & 1.316 & 0.896 \\
\hline Mean & & & 2.05 & 1.49 & 1.21 & \\
\hline SEM & & & 0.56 & 0.08 & 0.05 & \\
\hline
\end{tabular}

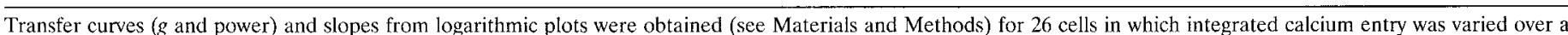

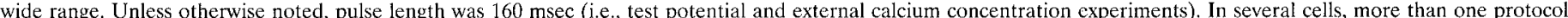

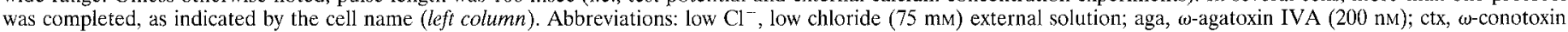
GVIA $(1 \mu \mathrm{M})$; nif, nifedipine $(10 \mu \mathrm{M})$; skf, SKF38393 $(10 \mu \mathrm{M})$; nis, nisoldipine $(10 \mu \mathrm{M})$; IV, current-voltage relationship; and Ext Ca, external calcium concentration.

the fusion apparatus. The highly ordered and reproducible manner in which individual chromaffin cells respond to integrated calcium entry, regardless of particular calcium entry characteristics, suggests that the probability of vesicle fusion depends on both the flux of calcium and the amount of time that calcium entry continues.

\section{Conclusions and future directions}

We have characterized the calcium dependence of large densecored vesicle exocytosis evoked by single depolarizations in the absence of activity-dependent facilitation or depression. Although stimulus-secretion coupling during physiological stimulation cannot be described exclusively by the law of mass action, we demonstrate here that the amount of exocytosis under conditions of minimal stimulation is highly regulated and tightly linked to the amount of calcium entry. The usefulness of a consistent input-output relationship for large dense-cored vesicle exocytosis is chiefly in establishing a baseline for comparison of control conditions to activity-dependent modifica- 
A

Figure 7. $\mathrm{N}$ - and $\mathrm{P} / \mathrm{Q}$-type calcium channels completely account for $\Delta \mathrm{Cm}$ responses evoked by single depolarizations. $A$, Individual $\mathrm{Cm}$ jumps in response to $160 \mathrm{msec}$ depolarizations to +20 mV: control (1); after application of 200 пм $\omega$-agaloxin IVA (2); after addition of $1 \mu \mathrm{M} \omega$-conotoxin (3), and after 10 prepulses to $+120 \mathrm{mV}$, to relieve the block by $\omega$-agatoxin (4). Data were fit to the equation $\Delta \mathrm{Cm}=g \times$ $\left(\Sigma \mathrm{Ca}^{2+} \text { entry }\right)^{X}$, with $g=0.9$ and $X=$ 1.5. B: Left, Calcium currents corresponding to the responses shown in $A$. Right, Difference currents, obtained by subtracting 2 from 1, top, and 3 from 4 , bottom, illustrating the kinetics of the $\omega$-agatoxin-sensitive current. Note that the current remaining in the presence of $\omega$-conotoxin and $\omega$-agatoxin (3) is completely inactivated by the end of the 160 msec voltage pulse, suggesting that it is attributable to residual, unblocked $\mathrm{N}$-type calcium channels rather than L-type calcium channels. Cell N031505.

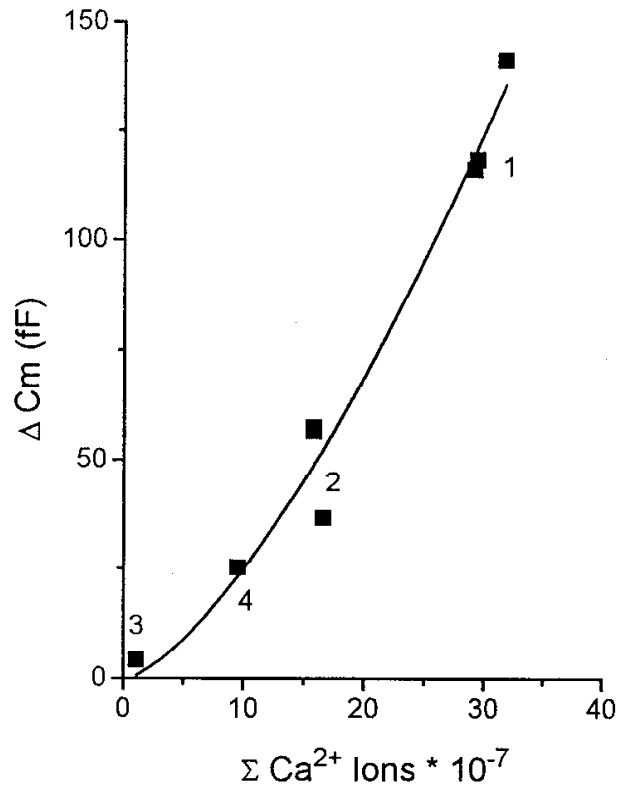

B
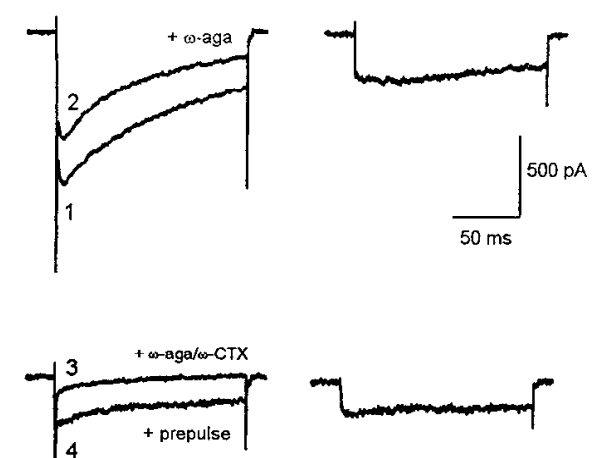

tions. We expect that processes of facilitation or depression will be revealed as deviations from the standard transfer function.

Stimulus-dependent exocytosis is a process that consists of many steps that we have only begun to elucidate. Secretory models will need to address the complexity of secretory behaviors observed in living cells. Empirical determination of the properties of each step in the secretory pathway, in combination with approaches to alter the amount or activity of individual proteins, will lead to an understanding of the fundamental mechanisms of calcium-dependent exocytosis at the molecular level.

\section{REFERENCES}

Ammala C, Eliasson L, Bokvist K, Larsson O, Ashcroft FM, Rorsman P (1993) Exocytosis elicited by action potentials and voltage-clamp calcium currents in individual mouse pancreatic B-cells. J Physiol (Lond) 472:665-668.

Artalejo CR, Ariano MA, Perlman RI, Fox AP (1990) Activation of facilitation calcium channels in chromaffin cells by $\mathrm{D} 1$ dopamine receptors through a cAMP/protein kinase A-dependent mechanism. Nature 348:239-242.

Artalejo CR, Adams ME, Fox AP (1994) Three types of $\mathrm{Ca}^{2+}$ channel trigger secretion with different efficacies in chromaffin cells. Nature 367:72-76.

Augustine GJ, Charlton MP (1986) Calcium dependence of presynaptic calcium current and postsynaptic response at the squid giant synapse. $\mathrm{J}$ Physiol (Lond) 381:619-640.

Augustine GJ, Neher E (1992) Calcium requirements for secretion in bovine chromaffin cells. J Physiol (Lond) 450:247 271

Figure 8. Calcium flux through L-type "facilitation" channels during singlestep depolarizations does not affect the relationship between exocytosis and integrated calcium entry. Individual $\mathrm{Cm}$ jumps were evoked by voltage steps from a holding potential of $-90 \mathrm{mV}$ to $+20 \mathrm{mV}$ for $10 \mathrm{msec}(1), 40 \mathrm{msec}(2)$, $160 \mathrm{msec}(3), 320 \mathrm{msec}(4)$, and $640 \mathrm{msec}(5)$ in the absence (filled squares) or presence (open squares) of the $\mathrm{D}_{1}$ dopamine-receptor agonist SKF-38393 (10 $\mu \mathrm{M})$. Data were fit to the equation $\Delta \mathrm{Cm}=0.24 \times\left(\Sigma \mathrm{Ca}^{2+}\right.$ ions) ${ }^{1.8}$. Inset, Calcium currents evoked by $40 \mathrm{msec}$ pulses. SKF-38393 increased the peak inward current by $-20 \%$, but for long duration pulses there was no net increase in integrated calcium entry, because of more rapid current inactivation in the presence of the agonist. The change in calcium current kinetics suggests that the relatively minor recruitment of the facilitation channel may have been obscured by a $D_{1}$ receptor-mediated inhibition of $N$ - or Q-type calcium current (Surmeier et al., 1995). Cell N032401.
Cooke JD, Okamoto K, Quastel DMJ (1973) The role of calcium in depolarization-secretion coupling at the motor nerve terminal. J Physiol (Lond) 228:459-497.

Cull-Candy SG, Miledi R, Trautmann A, Uchitel OD (1980) On the release of transmitter at normal, myasthenia gravis and myasthenic syndrome affected human endplates. J Physiol (Lond) 299:621-638.

Dodge FA, Rahamimoff R (1967) Cooperative action of calcium ions in transmitter release at the neuromuscular junction. J Physiol (Lond) 193:419-432.

Douglas WW (1968) Stimulus-secretion coupling: the concept and clues from chromaffin and other cells. Br J Pharmacol 34:451-474.

Dudel J (1981) The effect of reduced calcium on quantal unit current and release at the crayfish neuromuscular junction. Pflugers Arch 391:35-40. 
Fidler N, Fernandez JM (1989) Phase tracking: an improved phase detection technique for cell membrane capacitance measurements. Biophys J 56:1153-1162.

Gentry R, Ye L, Nemerson Y (1995) A microscopic model of enzyme kinetics. Biophys J 69:356-361.

Gillis KD, Pun RYK, Misler S (1991) Single cell assay of exocytosis from adrenal chromaffin cells using "perforated patch recording." Pflugers Arch 418:611-613.

Heinemann C, Chow RH, Neher E, Zucker RS (1994) Kinetics of the secretory response in bovine chromaffin cells following flash photolysis of caged $\mathrm{Ca}^{2+}$. Biophys $\mathbf{J}$ 67:2546-2557.

Horrigan FT, Bookman FJ (1993) Na channel gating charge movement is responsible for the transient capacitance increase evoked by depolarization in rat adrenal chromaffin cells (Abstr). Biophys J 64:101A.

Horrigan FI, Bookman FJ (1994) Releasable pools and the kinetics of exocytosis in adrenal chromaffin cells. Neuron 13:1119-1129.

Jenkinson DH (1957) The nature of the antagonism between calcium and magnesium ions at the neuromuscular junction. J Physiol (Lond) 138:434-444.

Ioshi C, Fernandez.IM (1988) Capacitance measurements: an analysis of the phase detector technique used to study exocytosis and endocytosis. Biophys J 53:885-892.

Katz B, Miledi R (1970) $\Lambda$ further study of the role of calcium in synaptic transmission. J Physiol (Lond) 207:789-801.

Lim NF, Nowycky MC, Bookman FJ (1990) Direct measurement of exocylosis and calcium currents in single vertebrate nerve terminals. Nature 344:449-451.

Llinas R, Steinberg IZ, Walton K (1981) Relationship between presynaptic calcium current and postsynaptic potential in squid giant synapse. Biophys J 33:323-352.

Llinas R, Sugimori M, Silver RB (1992) Microdomains of high calcium concentration in a presynaptic terminal. Science 256:677-679.

Lopez MG, Villarroya M, Lara B, Sierra RM, Albillos A, Garcia AG, Gandia I. (1994) Q- and I-type $\mathrm{Ca}^{2+}$ channels dominate the control of secretion in bovine chromaffin cells. FEBS Lett 349:331-337.

Mintz IM, Adams ME, Bean BP (1992a) P-type calcium channels in rat central and peripheral neurons. Neuron 9:85-95.

Mintz IM, Venema VJ, Swiderek KM, Lee TD, Bean BP, Adams ME (1992b) P-type calcium channels blocked by the spider toxin $\omega$-AgaIVA. Nature 355:827-829.

Neher E, Augustine GJ (1992) Calcium gradients and buffers in bovine chromaffin cells. J Physiol (Lond) 450:273-301.

Neher E, Marty A (1982) Discrete changes of cell membrane capacitance observed under conditions of enhanced secretion in bovine chromaffin cells. Proc Natl Acad Sci USA 79:6712-6716.

Neher E, Zucker RS (1993) Multiple calcium-dependent processes related to secretion in bovine chromaffin cells. Neuron 10:21-30.

Nowycky MC, Pinter MJ (1993) Time courses of calcium and calciumbound buffers following calcium influx in a model cell. Biophys $\mathrm{J}$ 64:77-91.
Peng Y-Y, Zucker RS (1993) Release of LHRH is linearly related to the time integral of presynaptic $\mathrm{Ca}^{2+}$ elevation above a certain threshold level in bullfrog sympathetic ganglia. Neuron 10: $465-473$.

Rae J, Cooper K, Gates P, Watsky M (1991) Low access resistance perforated patch recordings using amphotericin B. J Neurosci Methods 37:15-26.

Randall A, Tsien RW (1995) Pharmacological dissection of multiple types of $\mathrm{Ca}^{2+}$ channel currents in rat cerebellar granule neurons. J Neurosci 15:2995-3012.

Roberts WM (1994) Localization of calcium signals by a mobile calcium buffer in frog saccular hair cells. J Neurosci 14:3246-3262.

Sala F, Hernandez-Cruz A (1990) Calcium diffusion modeling in a spherical neuron: relevance of buffering properties. Biophys J 57:313-324.

Sather WA, Tanabe T, Zhang J-F, Mori Y, Adams ME, Tsien RW (1993) Distinctive biophysical and pharmacological properties of class A (B1) calcium channel $\alpha_{1}$ subunits. Neuron 11:291-303.

Schweizer FE, Betz H, Augustine GJ (1995) From vesicle docking to endocytosis: intermediate reactions of exocytosis. Neuron 14:689-696.

Seward EP, Chernevskaya NI, Nowycky MC (1995) Exocytosis in peptidergic nerve terminals exhibits two calcium sensitive phases during pulsatile calcium entry. J Neurosci 15:3390-3399.

Seward EP, Nowycky MC (1996) Kinetics of stimulus-coupled secretion in dialyzed bovine chromaffin cells: docked and threshold secretory modes. J Neurosci 16:553-562.

Stanley EF (1986) Decline in calcium cooperativity as the basis of facilitation at the squid giant synapse. J Neurosci 6:782-789.

Surmeier DJ, Bargas J, Hemmings Jr HC, Nairn AC, Greengard P (1995) Modulation of calcium currents by a D1 dopaminergic protein kinase/ phosphatase cascade in rat neostriatal neurons. Neuron 14:385-397.

Thomas P, Wong JG, Almers W (1993a) Millisecond studies of secrction in single rat pituitary cells stimulated by flash photolysis of caged $\mathrm{Ca}^{2+}$. EMBO J 12:303-306.

Thomas P, Wong JG, Lee AK, Almers W (1993b) A low affinity $\mathrm{Ca}^{22}$ receptor controls the final steps in peptide secretion in pituitary melanotrophs. Neuron 11:93-104.

Thomas-Reetz AC, De Camilli P (1994) A role for synaptic vesicles in non-neuronal cells: clues from pancreatic $\beta$-cells and from chromaffin cells. FASEB J 8:209-216.

Vitale ML, del Castillo AR, Tchakarov L, Trifaro J-M (1991) Cortical filamentous actin disassembly and scinderin redistribution during chromaffin cell stimulation precede exocytosis: a phenomenon not exhibited by gelsolin. J Cell Biol 113:1057-1067.

Wheeler DB, Randall A, Tsien RW (1994) Roles of N-type and Q-type $\mathrm{Ca}^{2+}$ channels in supporting hippocampal synaptic transmission. Science 264:107-111.

Zhou Z, Misler S (1995) Action potential-induced quantal secretion of catecholamines from rat adrenal chromaffin cells. J Biol Chem 270: 3498-3505. 